\title{
DETERMINATION OF THE CONCENTRATION OF METALS IN NOODLES FROM A MAJOR MARKET IN NIGERIA: A HEALTH RISK ASSESSMENT
}

\author{
Osobamiro, T. M.* and Hashimi, A. \\ Department of Chemical Sciences, Olabisi Onabanjo University, P.M.B. 2002, Ago-Iwoye, Nigeria \\ *E-mail: topebamiro@gmail.com,osobamiro.temitope@oouagoiwoye.edu.ng \\ Phone number: +234-0805-6628-102 \\ (Received: $13^{\text {th }}$ February, 2019; Accepted: $26^{\text {th }}$ May, 2020)
}

\section{ABSTRACT}

\begin{abstract}
This study evaluated the levels of $\mathrm{Na}, \mathrm{Ca}, \mathrm{Fe}, \mathrm{Cr}, \mathrm{Cd}$ and $\mathrm{Pb}$ in five different brands of instant noodles sold in a major market in Ogun State, Nigeria using Atomic Absorption Spectrophotometer after acid digestion. The associated non-carcinogenic risk of toxic metals in these noodles when ingested was estimated by calculating Chronic Daily Intake (CDI), Target Hazard Quotient (THQ) and Total Target Hazard Quotient (TTHQ). The results of the metals concentrations in the noodle samples were (in $\mathrm{mg} / \mathrm{kg}$ ) Na $\leq 13.8 \pm 0.9$, Ca $\leq 40.3 \pm 1.2, \mathrm{Cr} \leq$ $1.58 \pm 0.01, \mathrm{Fe} \leq 1.51 \pm 0.02, \mathrm{Cd} \leq 0.082 \pm 0.001$ and $\mathrm{Pb} \leq 0.001 \pm 0.000$, while in seasoning samples, $\mathrm{Na} \leq 18.2$ $\pm 1.4, \mathrm{Ca} \leq 38.7 \pm 2.1, \mathrm{Cr} \leq 1.18 \pm 0.02, \mathrm{Fe} \leq 1.58 \pm 0.01, \mathrm{Cd} \leq 0.041 \pm 0.001$ and $\mathrm{Pb}$ was below the detection limit of the instrument. The concentration of all the metals was below the WHO permissible standard in foods except for $\mathrm{Cr}$ in some brands. The level of $\mathrm{Na}$ in all the noodles and seasoning samples were less than the set targets by United Kingdom and South Africa for $\mathrm{Na}$ in foods. Chronic Daily Intake, THQ and TTHQ obtained for all the metals were less than unity but values for children were higher than that for adults. This result revealed that noodles consumption has no adverse non-cancer health effects over a lifetime; however, instant noodles should not be served alone as children meal but be supplemented.
\end{abstract}

Keywords: Instant noodles, metals, sodium, health risk, seasoning

\section{INTRODUCTION}

Noodles are widely consumed throughout the world and their consumption is second only to bread. Its sales have grown tremendously with the introduction of different brands in the market. This is because instant noodles are convenient, tasty, nutritious, of low cost and have relatively long shelf-life (Gulia et al., 2014). It is a popular meal commonly taken by both young and old oftentimes, and it is given as a complete meal to growing children (Ezekiel and Sombie, 2014). Instant noodles are dried or precooked fused with oil and often sold with a packet of flavoring including seasoning oil. Dried noodles are usually eaten after being cooked or soaked in boiling water, while precooked noodles can be reheated or eaten directly from the packet.

Instant noodles are often criticized as unhealthy or junk food, the monosodium glutamate (MSG) in the flavor packets usually contains high concentration of sodium which is added as flavor enhancer (Farrand et al., 2017). Allergy to MSG has been reported to produce burning sensations, chest and facial flushing, or pain and headaches. High sodium level is attributed as a key contributor to ill health across the world (Farrand et al., 2017). It is a major risk factor for cardiovascular and non-communicable diseases (NCDs). The global target of 30\% relative reduction in mean population of salt intake by 2025 has been recommended by WHO as less than $5 \mathrm{~g} /$ day (WHO, 2013; Mozaffarian et al., 2014).

Salt is added during the production of instant noodles at concentrations of $1-3 \%$ of flour weight; it is a major component of the seasoning included in the packaging of instant noodles. Salt is added to reduce cooking time, enhance flavour, provide a softer and more elastic texture, and inhibit enzyme activities and growth of microorganisms (Fu, 2007). The United Kingdom (UK) has set an average target between 200 and $350 \mathrm{mg}$ of sodium per $100 \mathrm{~g}$ of instant noodles (PHRD, 2014) while South Africa (SA) set its targets at $800 \mathrm{mg}$ of sodium per $100 \mathrm{~g}$ by 2019 (Government Gazette, 2013).

Contamination of food products by heavy metals is becoming an unavoidable problem these days. Air, land and water pollution are contributing to 
the presence of these harmful elements in food stuff including instant noodles (Onyema et al., 2014, Pirsaheb et al., 2016). Food processing equipment, containers, additives and packaging materials are some of the possible channels through which noodles can be contaminated with heavy metals (Jothi and Uddin, 2014, Omuku et al., 2014, Charles et al., 2018). Soil irrigation with contaminated water, fertilizer and pesticides application, industrial emissions, storage container, and road traffic with leaded petrol are some of the possible sources of heavy metals in wheat which serves as the main raw material for noodles production (Gholam and Jahead, 2005; Ihedioha, et al., 2018).

Human exposure to heavy metals, a group of nonbiodegradable and persistent environmental contaminants, from food has increased in recent years. Ingestion and bio-accumulation of high concentrations of heavy metals through food products can cause damages to the heart, nervous system, liver, kidney, blood, lungs, bone, and spleen (Ghasemidehkordi et al., 2018, Fathabad et al., 2018). Cadmium has been reported to interfere with some essential functions of $\mathrm{Zn}$, inhibiting enzyme reactions and nutrient utilization (Afiukwa, 2013). Lead affects the peripheral and central nervous systems, renal functions and blood cells. High level of lead has been associated with hypertension, reproductive, developmental and neurological disorders (Jarup, 2003). Higher levels of some of these heavy metals in noodles have been reported in literature. For example, high levels of arsenic, lead and copper have been reported in noodles from Taiwan, high levels of lead in Maggi noodles from India, (Ihedioha et al., 2018) and also in Bangladesh (Jothi and Uddin, 2014).

Heavy metal concentrations in food products need to be continuously monitored for quality assurance and safety. Information on the levels of these in commercially available noodles is significant to evaluate the possible health risks associated with their consumption. This study therefore, was undertaken to determine the levels of some essential $(\mathrm{Na}, \mathrm{Ca}, \mathrm{Fe})$ and non-essential metals $(\mathrm{Cr}, \mathrm{Cd}$ and $\mathrm{Pb})$ in noodles, their seasoning pack and to evaluate the health risks due to their regular and unguarded consumption.

\section{MATERIALS AND METHODS}

\section{Sample Collection and Digestion}

The samples collected consist of five different brands of instant noodles (coded A, B, C, D, E) commonly consumed in Ogun State. Samples of noodles were randomly selected from the composite, ground into powder and kept for further analysis. The seasoning packed with each selected noodle sample was labeled as samples $\mathrm{Sa}$ to Se. In each case, $1 \mathrm{~g}$ of the sample (noodles and seasoning) was weighed in duplicate into separate Teflon beakers using analytical weighing balance. Thereafter, $10 \mathrm{~mL}$ of Nitric acid $\left(\mathrm{HNO}_{3}\right)$ was added, covered with a watch glass and the mixture was heated over a hot plate at a temperature of 120 $-150^{\circ} \mathrm{C}$ in a fume cupboard until digestion was complete. The digested solution was made up to mark in a $50 \mathrm{~mL}$ volumetric flask. The concentrations of $\mathrm{Na}, \mathrm{Ca}, \mathrm{Cr}, \mathrm{Fe}, \mathrm{Cd}$ and $\mathrm{Pb}$ in the filtrate were determined using Atomic Absorption Spectrophotometer (Buck Model 205). In order to correct chemical and ionization interference in $\mathrm{Na}$ determination, $1 \mathrm{~mL}$ of Cesium Chloride solution was added to each of the standard and sample solutions (Julshamn et al., 2005).

\section{Quality Assurance}

Quality assurance and quality control protocols used include: procurement of analytical grade Nitric acid from Sigma Aldrich; recovery studies (spiking), and blank determination. Appropriate standard solutions prepared from analar grade salts were used to calibrate the Atomic Absorption Spectrophotometer prior to measurement of metal concentrations. The detection limit of the instrument was evaluated using blank signal plus three times the standard deviation of the blank signal for each metal.

\section{Health risk assessment}

The health risk assessment of consuming toxic metals ( $\mathrm{Cr}$ and $\mathrm{Cd}$ ) in instant noodles considered in this study was evaluated by calculating the Chronic Daily Intake (CDI) and Target Hazard Quotient (THQ). Pb was not included because its concentration was below the detection limit for most of the samples. The Chronic Daily Intake (CDI) $(\mathrm{mg} / \mathrm{kg} /$ day) of $\mathrm{Cr}$ and $\mathrm{Cd}$ in instant noodles was estimated using Equation 1 (Heshmati et al., 2018; Keramati et al., 2018). 
$C D I=\frac{\mathrm{C} \times \mathrm{EDi} \times \mathrm{IRi} \times \mathrm{EFi}}{\mathrm{BW} \times \mathrm{ATn}}$

where $\mathrm{C}=$ concentration of heavy metals $\mathrm{mg} / \mathrm{kg}$, IRi (Ingestion rate, $\mathrm{kg} / \mathrm{n}$-day) $=0.0027$ (WINA 2018), EFi (Exposure frequency, days/year) = 350, Edi (Exposure duration, years): Adults = 30; and children $=6$ (EPA, 2011), BWi (Body weight, $\mathrm{kg}):$ Adults $=70$ and children $=20$, ATn (Average time exposure, days): Adults $=10550$ and children $=2100($ EPA 2011).

The non-carcinogenic risk of $\mathrm{Cr}$ and $\mathrm{Cd}$ due to direct ingestion of instant noodle was estimated using Target Hazard Quotient (THQ) according to Equation 2 (EPA, 2011; Fakhri et al., 2018).

$T H Q=\frac{\mathrm{CDI}}{\mathrm{RFd}}$

If $\mathrm{THQ}>1$ value, potentially adverse health effect is likely; while THQ $\leq 1$ value, adverse health effect is not likely (EPA, 2011; Abtahi et al., 2017, Fakhri et al., 2017).
The health risk of multiple heavy metals in the instant noodle and the seasoning was calculated. This was done by summing THQ for individual heavy metal using Equation 3 (EPA 2011, Razzaghi et al., 2018)

$\mathrm{TTHQ}=\mathrm{THQ}_{1}+\mathrm{THQ}_{2}+\ldots+\mathrm{HQ} \mathrm{n}$

\section{RESULTS AND DISCUSSION}

The results of the quality assurance in terms of calibration curves, detection limits of instrument and percentage recovery were presented in table 1 . Correlation values $\left(\mathrm{r}^{2}\right)$ of the calibration curves for metals showed high linearity ranges from 0.829 to 0.983. Na has the highest detection limit while $\mathrm{Cd}$ has the lowest. The $\%$ recoveries of all the studied metals are higher than $80 \%$ with $\mathrm{Na}$ having the lowest and $\mathrm{Cr}$ the highest. The correlation values $\left(\mathrm{r}^{2}\right)$, the detection limits and \% recoveries of all the metals are within the acceptable range indicating that the results are reliable and accurate.

Table 1: AAS calibration, detection limit and $\%$ recovery of the metals in noodles samples

\begin{tabular}{rrrr}
\hline Metal & $\begin{array}{r}\text { Calibration } \\
\text { Curve, } \mathrm{r}^{2}\end{array}$ & $\begin{array}{r}\text { Calculated } \\
\text { DL }(\mathrm{mg} / \mathrm{kg})\end{array}$ & \multicolumn{1}{l}{ Recovery } \\
\hline $\mathrm{Na}$ & 0.829 & 0.231 & $81.9 \pm 2.1$ \\
$\mathrm{Ca}$ & 0.892 & 0.017 & $90.3 \pm 3.2$ \\
$\mathrm{Cr}$ & 0.982 & 0.014 & $95.2 \pm 3.3$ \\
$\mathrm{Fe}$ & 0.983 & 0.013 & $93.4 \pm 3.1$ \\
$\mathrm{Cd}$ & 0.894 & 0.004 & $92.7 \pm 4.2$ \\
\hline
\end{tabular}

DL - Detection Limit

Table 2: Concentrations of the metals $(\mathrm{mg} / \mathrm{kg})$ in the noodle samples

\begin{tabular}{lllllll}
\hline Sample & $\mathrm{Na}$ & $\mathrm{Ca}$ & $\mathrm{Cr}$ & $\mathrm{Fe}$ & $\mathrm{Cd}$ & $\mathrm{Pb}$ \\
\hline $\mathrm{A}$ & $11.7 \pm 0.9$ & $7.89 \pm 0.12$ & $1.65 \pm 0.03$ & $0.74 \pm 0.00$ & $0.043 \pm 0.001$ & $\mathrm{BDL}$ \\
$\mathrm{B}$ & $12.3 \pm 0.8$ & $8.01 \pm 0.32$ & $\mathrm{BDL}$ & $0.60 \pm 0.00$ & $0.072 \pm 0.001$ & $\mathrm{BDL}$ \\
$\mathrm{C}$ & $12.1 \pm 0.6$ & $9.55 \pm 0.31$ & $1.58 \pm 0.01$ & $1.01 \pm 0.01$ & $0.077 \pm 0.002$ & $0.001 \pm 0.000$ \\
$\mathrm{D}$ & $12.2 \pm 0.7$ & $11.30 \pm 0.60$ & $0.61 \pm 0.00$ & $1.29 \pm 0.01$ & $0.038 \pm 0.001$ & $\mathrm{BDL}$ \\
$\mathrm{E}$ & $13.8 \pm 0.9$ & $40.30 \pm 1.20$ & $0.02 \pm 0.00$ & $1.51 \pm 0.02$ & $0.082 \pm 0.001$ & $\mathrm{BDL}$ \\
Mean & $12.4 \pm 0.8$ & $15.40 \pm 1.10$ & $0.77 \pm 0.00$ & $1.03 \pm 0.01$ & $0.062 \pm 0.001$ & $0.000 \pm 0.000$ \\
WHO & $<35^{*}$, & & 0.05 & 10.0 & 0.03 & 0.50 \\
Std & $<80^{* *}$ & & & & & \\
\hline
\end{tabular}

*WHO std- World Health Organization standard; **Set targets by the United Kingdom and South Africa. 
Table 3: The concentration of the metals in the noodles seasoning

\begin{tabular}{lllllll}
\hline Sample & $\mathrm{Na}(\mathrm{mg} / \mathrm{kg})$ & $\mathrm{Ca}(\mathrm{mg} / \mathrm{kg})$ & $\mathrm{Cr}(\mathrm{mg} / \mathrm{kg})$ & $\mathrm{Fe}(\mathrm{mg} / \mathrm{kg})$ & $\mathrm{Cd}(\mathrm{mg} / \mathrm{kg})$ & $\begin{array}{l}\mathrm{Pb} \\
(\mathrm{mg} / \mathrm{kg})\end{array}$ \\
\hline $\mathrm{Sa}$ & $17.6 \pm 1.3$ & $8.58 \pm 0.1$ & $0.081 \pm 0.002$ & $0.467 \pm 0.001$ & $0.021 \pm 0.000$ & $\mathrm{BDL}$ \\
$\mathrm{Sb}$ & $16.8 \pm 0.8$ & $10.7 \pm 0.8$ & $0.035 \pm 0.001$ & $0.406 \pm 0.001$ & $0.014 \pm 0.000$ & $\mathrm{BDL}$ \\
$\mathrm{Sc}$ & $16.9 \pm 1.0$ & $15.2 \pm 1.1$ & $0.759 \pm 0.021$ & $0.896 \pm 0.002$ & $0.041 \pm 0.001$ & $\mathrm{BDL}$ \\
$\mathrm{Sd}$ & $18.2 \pm 1.4$ & $17.1 \pm 0.9$ & $0.653 \pm 0.015$ & $0.775 \pm 0.002$ & $0.031 \pm 0.000$ & $\mathrm{BDL}$ \\
$\mathrm{Se}$ & $17.5 \pm 0.9$ & $38.7 \pm 2.1$ & $1.180 \pm 0.020$ & $1.580 \pm 0.010$ & $0.037 \pm 0.000$ & $\mathrm{BDL}$ \\
Mean & $17.4 \pm 0.8$ & $18.1 \pm 0.9$ & $0.602 \pm 0.014$ & $0.824 \pm 0.001$ & $0.029 \pm 0.000$ & $\mathrm{BDL}$ \\
\hline
\end{tabular}

Mean Standard Deviation

The results of the analysis of metals in noodles and seasoning samples sold in commercial market were presented in tables 2 and 3 respectively. From the results presented in Table 2 for metal content in the noodles, $\mathrm{Na}$ had the highest concentration while the concentration of $\mathrm{Pb}$ in most samples was below the detection limit of the instrument. Sample E contained the highest concentrations of $\mathrm{Na}, \mathrm{Ca}, \mathrm{Fe}$ and $\mathrm{Cd}$ while sample A contained the lowest concentration of $\mathrm{Na}$ and $\mathrm{Ca}$. In the analyzed seasoning samples, sample $\mathrm{Sd}$ had the highest $\mathrm{Na}$ content while $\mathrm{Pb}$ was found to be below the detection limit of the instrument for all the seasoning samples. Calcium level in seasoning sample Se was found to be the highest, similar to the content in noodle sample $\mathrm{E}$. The concentration of $\mathrm{Na}$ in all the seasoning samples was higher than the content in the noodle samples but all are less than the set targets by the United Kingdom (PHRD, 2014) and South Africa (Government Gazette2013) (Tables 2 and 3). The concentrations of all the analysed metals in both noodles and seasonings were compared with permissible limits set by WHO (2011) and were all found to be significantly below the set standard except some for $\mathrm{Cr}$ in some of the samples (Table 3). Calcium and Fe are two of the essential metals required by the body and, to a lesser extent $\mathrm{Cr}$, but $\mathrm{Cd}$ and $\mathrm{Pb}$ are toxic to the body (Charles et al., 2018).

The level of $\mathrm{Cd}$ recorded in both noodle and seasoning samples was $\leqslant 0.082 \mathrm{mg} / \mathrm{kg}$ and all were found to exceed the permissible levels set by WHO $(0.003 \mathrm{ig} / \mathrm{g})$ and FDA $(0.005 \mathrm{mg} / \mathrm{kg})$ for Cd (WHO, 2011; Tomori and Onibon, 2015) except seasoning samples $\mathrm{Sa}$ and $\mathrm{Sb}$, but less than Codex Alimentarius standard for $\mathrm{Cd}$ in cereals $(0.1$ $\mathrm{mg} / \mathrm{kg}$ ) (Codex Alimentarius, 2008). Cadmium level in this study was higher than the level reported by Onyema et al. (2014) and Ihedioha et al. (2018) in instant noodles from Nigeria but less than the level reported by Tajdar-oranj et al. (2018) and Jothi and Uddin (2014) in noodles from Iran and Bangladesh.

The levels of $\mathrm{Pb}$ in most of the noodles and seasoning samples were below detection limit; this is not in accordance with the report of earlier workers who reported detectable levels in their findings (Onyema et al., 2014; Charles et al., 2018; Ihedioha et al., 2018; Tajdar-oranj et al., 2018). The recommended maximum level for $\mathrm{Pb}$ in noodles is $2(\mathrm{mg} / \mathrm{kg})$ according to the Bangladesh Standards and Testing Institution (BSTI), (Jothi and Uddin, 2014). Permissible limits set by the Codex Alimentarius and $\mathrm{WHO}$ for the $\mathrm{Pb}$ in cereals and food products are 0.2 and $0.025(\mathrm{mg} / \mathrm{kg})$ respectively (Codex Alimentarius, 2008, Charles et al., 2018).

The concentration of $\mathrm{Cr}$ in instant noodle samples ranged from 0.023 to $1.650(\mathrm{mg} / \mathrm{kg})$ while in seasoning samples the values ranged from 0.081 to $1.180(\mathrm{mg} / \mathrm{kg})$. Chromium concentration in noodle samples B, E and seasoning sample B were below the defined limit by WHO, while all others were above the standard $(0.05 \mathrm{mg} / \mathrm{kg})$. This result is higher than the result reported by Onyema et al. (2014), Ihedioha et al. (2018) and Tajdar-oranj et al. (2018), but fell within the range of the result reported by Charles et al. (2018) in noodles sold in Port Harcourt market.

Although, little amount of $\mathrm{Na}$ is required by the body for proper functioning, but if the daily intake is exceeded, this could result into high blood pressure, kidney diseases and the body may even 
experience inability to properly absorb the sodium consumed (WHO, 2011). On the other hand, if the required sodium is not enough per day, low sodium could result into the body's inability to maintain healthy fluid levels and could also have a negative impact on the way the muscles expand and contract, especially during exercise (WHO, 1996).

\section{Health risk assessment}

The health risk assessment of the two toxic metals ( $\mathrm{Cr}$ and $\mathrm{Cd}$ ) determined in this study were evaluated by calculating the Chronic Daily Intake (CDI), Target Hazard Quotient (THQ) and Total Target Hazard Quotient (TTHQ). The results of the calculated CDI, THQ and TTHQ were presented in Tables 4 and 5 respectively. The CDI for $\mathrm{Cr}$ is a bit higher than that of $\mathrm{Cd}$ for both noodle and seasoning samples and all were less than 1.0. THQ values (i.e. the ratio between the measured concentrations and the oral reference dose) were calculated for $\mathrm{Cr}$ and $\mathrm{Cd}$ in the noodle and seasoning samples. The total hazard Quotient (TTHQ) is a sum of the individual hazard quotients of each metal. The THQ for $\mathrm{Cd}$ is higher than that of $\mathrm{Cr}$ for both noodle and seasoning samples and both THQ and TTHQ obtained for all the metals were less than 1.0. TTHQ for children is more than that for adults. This is not in accordance with the findings of Tajdar-oranj et al. (2018) and Charles et al. (2018) who recorded higher TTHQ for adult consumers. THQ and TTHQ exposures below 1.0 have been reported not to result in adverse non-cancer health effects over a lifetime of exposure (Charles et al., 2018; Thedioha et al., 2018, Tajdar-oranj et al., 2018).

Table 4. Estimated Chronic Daily Intake (CDI) ( $\mathrm{mg} / \mathrm{kg} /$ day) of heavy metals in the samples

\begin{tabular}{lccll}
\hline & Metals & Metals $(\mathrm{mg} / \mathrm{kg})$ & Children & Adult \\
\hline \multirow{2}{*}{ Noodles } & Cr & $0.774 \pm 0.001$ & $1.05 \times 10^{-4}$ & $2.97 \times 10^{-5}$ \\
& Cd & $0.062 \pm 0.001$ & $8.37 \times 10^{-6}$ & $2.38 \times 10^{-6}$ \\
\multirow{2}{*}{ Seasoning } & Cr & $0.602 \pm 0.014$ & $8.13 \times 10^{-5}$ & $2.31 \times 10^{-5}$ \\
& Cd & $0.029 \pm 0.000$ & $3.92 \times 10^{-6}$ & $1.11 \times 10^{-6}$ \\
\hline
\end{tabular}

Table 5. Target Hazard Quotient and Total Target Hazard Quotient of Cr and Cd in the samples

\begin{tabular}{llll}
\hline & metals & Children & Adult \\
\hline \multirow{2}{*}{ Noodles } & Cr & $7.00 \times 10^{-5}$ & $1.98 \times 10^{-5}$ \\
& Cd & $8.37 \times 10^{-3}$ & $2.38 \times 10^{-3}$ \\
\multirow{2}{*}{ Seasoning } & Cr & $5.42 \times 10^{-5}$ & $1.54 \times 10^{-5}$ \\
& Cd & $3.92 \times 10^{-3}$ & $1.11 \times 10^{-3}$ \\
& TTHQ & $1.24 \times 10^{-2}$ & $3.53 \times 10^{-3}$ \\
\hline
\end{tabular}

However, a TTHQ greater than 1.0 does not necessarily suggest a likelihood of adverse effects. This is based on the fact that ingested dose is not equal to the absorbed pollutant dose because a fraction of the ingested toxicant may be excreted, leaving a smaller portion to accumulate in the body tissues (Horiguchi et al., 2004, Zhuang et al., 2009).

\section{CONCLUSION}

The concentrations of some essential and nonessential metals were determined in commonly consumed instant noodles and seasoning samples. The study revealed that most of these metals were below the permissible levels set by WHO in food. The $\mathrm{Na}$ level in all the noodles and seasoning samples were less than the set targets by United Kingdom and South Africa for $\mathrm{Na}$ in food. The health risk assessment indicated that eaten any of 
the noodles brands cannot result in adverse noncancer health effects. Though, the levels of the metal contamination and the health risk assessment is low, instant noodles should not be served as a wholesome meal to children and there should be continuous monitoring of possible contaminants for food quality assurance and safety.

\section{REFERENCES}

Abtahi, M., Fakhri, Y., Oliveri Conti, G., Keramati, H., Zandsalimi, Y., Bahmani, Z., Hosseini Pouya, R., Sarkhosh, M., Moradi, B. and Amanidaz, N. 2017. Heavy metals (As, Cr, $\mathrm{Pb}, \mathrm{Cd}$ and $\mathrm{Ni}$ ) concentrations in rice (Oryza sativa) from Iran and associated risk assessment: a systematic review. Toxin Rev. 36, 331-341.

Afiukwa, J. N. 2013. Evaluation and correlation study of heavy metals load in drinking water and update of water-related disease cases in Ebonyi State from 2001 2011. AmerJ Sci Ind Res. 4, 221-225.

Charles, I. A., Ogbolosingha, A. J. and Afia, I. U. 2018. Health risk assessment of instant noodles commonly consumed in Port Harcourt, Nigeria. Environ Sci Pollut Res. $25, \quad 2580-2587$.

Codex Alimentarius. 2008. Codex General Standard for contaminants and toxins in food and feed. Codex Stan 9, 193-1995.

EPA. 2011. Exposure Factors Handbook, 2011 edition, EPA/600/r-09

Ezekiel, C. N. and Sombie, J. I. 2014. Survey of aflatoxins and fungi in some commercial breakfast cereals and pasta retailed in Ogun State, Nigeria. Nat Sci. 12, 27 - 32.

Fakhri, Y., Mohseni-Bandpei, A, Conti, G. O., Keramati, H., Zandsalimi, Y., Amanidaz, N., Hosseini Pouya, R., Moradi, B., Bahmani, Z. and Rasouli Amirhajeloo, L. 2017. Health risk assessment induced by chloroform content of the drinking water in Iran: systematic review. Toxin Rev. 36, 342-351.

Fakhri, Y., Mohseni-Bandpei, A., Conti, G. O., Ferrante, M., Cristaldi, A., Jeihooni, A. K., Dehkordi, M. K., Alinejad, A., Rasoulzadeh, H. and Mohseni, S. M. 2018. Systematic review and health risk assessment of arsenic and lead in the fished shrimps from the Persian gulf. Food Chem Toxicol.113, 278-286.

Farrand, C., Charlton, K., Crino, M., Santos, J., Rodriguez-Fernandez, R., Ni Mhurchu, C. and Webster, J. 2017. Know Your Noodles! Assessing Variations in Sodium Content of Instant Noodles across Countries. . 9, 612. doi: $10.3390 / \mathrm{nu} 9060612$

Fathabad, A. E., Shariatifar, N., Moazzen, M., Nazmara, S., Fakhri, Y., Alimohammadi, M., Azari, A. and Khaneghah, A. M. 2018. Determination of heavy metal content of processed fruit products from Tehran's market using ICP-OES: a risk assessment study. Food Chem Toxicol. 115, 436-446.

$\mathrm{Fu}$, B. X. 2007. Asian noodles: History, classification, raw materials and processing. Food Res. Int. 41, 888-902.

Ghasemidehkordi, B., Malekirad, A. A., Nazem, H., Fazilati, M., Salavati, H., Shariatifar, N., Rezaei, M., Fakhri, Y. and Khaneghah, A. M. 2018. Concentration of lead and mercury in collected vegetables and herbs from Markazi province, Iran: a noncarcinogenic risk assessment. Food Chem Toxicol. 113, 204-210

Gholam, R. and Jahead, K. 2005. Determination of Zinc contents in Iranian Breads. Pakistan J Nutr. 4, 294-297.

Government Gazette. 2013. No. R. 214 Foodstuffs, Cosmetics and Disinfectants Act, 1972 (Act 54 of 1972) Regulations Relating to the Reduction of Sodium in Certain Foodstuffs and Related Matters The Heart and Stroke Foundation South Africa. South Africa Government, Pretoria, South Africa.

Gulia, N., Dhaka, V. and Khatkar, B. 2014. Instant noodles: processing, quality, and nutritional aspects. Crit Rev Food Sci Nutr. 54, 1386-1399.

Heshmati, A., Ghadimi, S., Mousavi Khaneghah, A., Barba, F. J., Lorenzo, J. M., Nazemi, F. and Fakhri, Y. 2018. Risk assessment of benzene in food samples of Iran's market. Food Chem Toxicol.114, 278-284.

Horiguchi, H., Oguma, E., Sasaki, S., Miyamoto, K., Ikeda, Y., Machida, M. and Kayama, F. 2004. Dietary exposure to cadmium at close to the current provisional tolerable 
weekly intake does not affect renal function among female Japanese farmers. Environ Res. 95, 20-31.

Ihedioha, J. N., Atiatah, I. M., Ekere, N. R. and Asegbeloyin, J. N. 2018. Levels of Heavy Metals in Pasta Available in the Nigerian Market: Assessing the Human Health Implications. Journal of Chemical Health Risks, 8, 95-105.

Jarup, L. 2003. Hazards of heavy metal contamination. British Med Bull. 68, 167 182.

Jothi, J. S. and Uddin, M. B. 2014. Detection of heavy metals in some commercial brands of noodles. Eur Acad Res. 2, 10667 10677.

Julshamn, K., Lea, P. and Sloth, J. J. 2005. Determination of Sodium in Foods by Flame Atomic Absorption Spectrometry after Microwave Digestion: NMKL Interlaboratory Study. Journal of $A O A C$ International 88, 1212-1216.

Keramati, H., Miri, A., Baghaei, M., Rahimizadeh, A., Ghorbani, R., Fakhri, Y., Bay, A., Moradi, M., Bahmani, Z., Ghaderpoori, M. and Khaneghah, A. M. 2018. Fluoride in Iranian drinking water resources: a systematic review, Meta-analysis and Noncarcinogenic Risk Assessment. Biol Trace Elem Res.1-13.

Mozaffarian, D., Fahimi, S., Singh, G.M., Micha, R., Khatibzadeh, S., Engell, R.E., Lim, S., Danaei, G., Ezzati, M. and Powles, J. 2014. Global sodium consumption and death from cardiovascular causes. N. Engl. J. Med.371, 624-634.

Omuku, P. E., Onwumelu, H. A. and Alisa, C. O. 2014. Comparative analysis of selected heavy metals in green leafy vegetables and instant noodles sold in Eke-Awka market, Awka, Anambra state. Journal of Environmental Science and Water Resources 3, $209-213$.

Onyema, C. T., Ekpunobi, U.E., Edowube, A. A., Odinma, S. and Sokwaibe, C. E. 2014. Quality Assessment of Common Instant Noodles Sold in Nigeria Markets. American Journal of Analytical Chemistry, 5,
1174-1177.

PHRD. 2014. Public Health Responsibility Deal: UK Salt Reduction Targets for 2017. UK Department of Health; London, UK.

Pirsaheb, M., Fattahi, N., Sharafi, K., Khamotian, R. and Atafar, Z. 2016. Essential and toxic heavy metals in cereals and agricultural products marketed in Kermanshah, Iran, and human health risk assessment. Food Addit Contam. Part B 9, 15-20.

Razzaghi, N., Ziarati, P., Rastegar, H., Shoeibi, S., Amirahmadi, M., Conti, G.O., Ferrante, M., Fakhri, Y. and Khaneghah, A. M. (2018). The concentration and probabilistic health risk assessment of pesticide residues in commercially available olive oils in Iran. Food Chem Toxicol. 120,32-40.

Tajdar-oranj, B., Shariatifar, N., Alimohammadi, M., Peivasteh-roudsari, L., Khaniki, G. J., Fakhri, Y. and Khaneghah, A. M. 2018. The concentration of heavy metals in noodle samples from Iran's market: probabilistic health risk assessment. Environ Sci Pollut Res. https://doi.org/10.1007/s11356-0183030-y

Tomori, W.B. and Onibon, V.O. 2015. Health risk assessment of metal content in wheat based snacks from three different kitchen types in Akure metropolis. FUTA J Res Sci. 1, 157-170.

WHO. 2011. Evaluation of certain contaminants in food: seventy-second report of the Joint FAO/WHO Expert Committee on Food Additives. World Health Organization.

WHO. 2013. Global Action Plan for the Prevention and Control of Noncommunicable Diseases 2013-2020. World Health Organization; Geneva, Switzerland.

Zhuang, P., McBride, M. B., Xia, H., Li, N. and Li, Z. 2009. Health risk from heavy metals via consumption of food crops in the vicinity of Dabaoshan mine, South China. Sci TotalEnviron. 407, 1551-1561. 